\title{
The Dangers of Decentralization Clientelism, the State, \& Nature in a Democratic Indonesia ${ }^{*}$ \\ Shane Joshua Barter, University of British Columbia Department of Political Science, PhD Candidate
}

Throughout the Cold War and after, Southeast Asian dictatorships lay somewhere between predatory and developmental states, posting high growth rates but with equally high costs. Rulers such as Sarit, Marcos, and Suharto were surrounded by networks of patrons and clients that went all the way to the village level. These regimes were as agnostic towards environmental effects of their modernization programmes as they were towards democracy, the rule of law, and the rights of their citizens. Even though economic growth improved the livelihoods of their populations, Southeast Asian countries were left with weak states, clientelist social structures, and severe environmental damage. A solution offered by activists and academics alike was the creation of decentralized, democratic systems where communities could have greater control over political power and natural resources. The 'Third Wave' of democratization in Southeast Asia, from 14 October, to EDSA, to Reformasi helped realize these hopes.

In Indonesia, the fall of Suharto, fair elections, and radical decentralization have brought impressive changes. But in remote regions and specific sectors, decentralization has meant a weaker state, more clientelism, and continued environmental destruction. This presents the kind of conceptual puzzle so sought after by academics, with real-world implications cherished by activists and governments. What accounts for the uneven impacts of democratization and decentralization on state capacity and corruption, and what does this mean for environmental sustainability?

This essay is an initial stride towards a larger research project on institutional change and illegal logging in Indonesia. ${ }^{1}$ The first section examines theories of state and society. I begin by discussing Migdal's weak state, strong society model to illustrate the challenges faced by reformers. Then I turn to clientelism, a persistent form of social organization which explains why weak states face continued resistance. In the second section, I look at centralized rule and

\footnotetext{
${ }^{*}$ Thank you to Herwin, Hardi, Ima, and Cheker at OPPUK in Medan as well as Bari at WALHI in Banjarmarsin for their help and friendship in the field. Back on campus, thank you to Ken Foster, Diane Mauzy, and the reviewers at Federal Governance for their suggestions. Field research was made possible by Peter Dauvergne and the Social Science and Humanities Research Council. As always, any errors are the fault of the author.
} 
clientelism in Indonesia. In the third, I turn to the ongoing experiment of radical decentralization in Indonesia and its initial effects on illegal logging. I conclude with a tentative look forward.

It should be made clear that I am not critical of decentralization. I argue that decentralization is a necessary, but not a sufficient step to achieve greater accountability and sustainability. When controls from above are eliminated, it is important that checks from below are already in place. Without democracy, decentralization may compound the problems created by clientelist systems. The relationship between democracy and decentralization is partially reinforcing; decentralization first requires democracy to be effective, while decentralization deepens democracy by allowing local autonomy, greater responsiveness, and more effective representation. Decentralizing a clientelist system may simply cut the top off the pyramid, eliminating the central governments that held lower levels in check.

\section{I: State \& Society, Power \& Structure}

This section introduces two related concepts which help explain why illegal logging persists. First, Migdal's 'weak state' approach illustrates why some countries lack control over policy sectors which are dominated by strong societal forces. Second, I discuss clientelism, a form of social organization which undermines state capacity and drives various forms of corruption, including illegal logging. This will lead me to a discussion of these concepts in the context of Indonesia.

In recent years, political scientists have attempted to 'bring the state back in'. Early political science was mostly concerned with a state's formal structures, but after World War Two, the discipline shifted to a society-oriented one. In the 1980s, a number of scholars spearheaded a return to formal theorizing about the state: its evolution, autonomy, capacity, and institutions. While they demanded greater attention to the state, these scholars did not suggest a new grand theory at the expense of an emphasis on society. For Skocpol, "bringing the state back in...does not require a break with some of the most encompassing social-determinist assumptions of pluralism, structural functionalist developmentalism, and various neo-Marxisms." ${ }^{2}$ As a result, political scientists increasingly view state and society as codetermined.

Migdal exemplifies state / society approaches. In Strong Societies and Weak States, he examines "the capabilities of states to achieve the kinds of changes that their leaders have sought." ${ }^{3}$ Why are some states capable of doing what they want while others remain weak? 
Migdal responds that the state must compete with societal organizations for the ability and the right to define rules. To illustrate this struggle, Migdal creates a matrix of strong states with weak societies (Western democracies), strong societies with weak states (developing countries) and weak states with weak societies (anarchy). In later work, Migdal develops what he calls the 'state in society' perspective, an anthropology of the state which portrays it as one of several groups competing over legitimate authority. At each end of the continuum, there exist ideal types in which the state or society engulf one another. Most political systems feature a degree of states incorporating societal forces or societal forces incorporating the state. ${ }^{4}$

Dauvergne makes a useful modification to Migdal's approach in his analysis of forestry. Dauvergne's analysis disaggregates state and societal power by policy sector. Even weak states might dominate fiscal policy or road construction, which are high priorities with little social resistance. In contrast, environmental laws are "generally a low priority for states", but "are often quite threatening to nonstate organizations, particularly powerful businesses." ${ }^{\text {"Th }}$ Thus, in the forestry sectors of large, resource-rich developing countries, states will be especially weak and social organizations such as corporations and militaries will be especially strong.

How do democratization and decentralization affect state capacity? Migdal's strong states are predominately democracies. Democracy enhances participation and legitimacy, two of Migdal's three indicators of social control, so that society acts through state institutions. ${ }^{6}$ Democracy alters societal power, promoting some actors such as associations, small businesses, the media, and NGOs while weakening societal powers which are more likely to rival the state, such as militaries or corporations. If democracy takes root, decentralization may create a state which is more capable of achieving its goals because its units can best react to local conditions. If democracy is absent, decentralization may empower strong societal actors such as local strongmen or corporations to resist the state.

In many developing countries, the state remains weak because it fails to penetrate "weblike" social structures. Patron-client relationships are instrumental interactions where clients bargain for access from patrons in exchange for support. The patron may provide funds, resources, licenses, or protection in exchange for loyalty, rents, or support. Although asymmetrical, these relationships are not always exploitative. Patron-client relationships can be mutually beneficial, self-enforcing, personal, and difficult for weak states to overcome. Clientelism is a pyramid-shaped system of patron-client relationships in which most actors are 
both patrons and clients at some level. Such systemic patron-client relationships result in ineffective laws, weak state legitimacy, and insufficient tax revenue. Compared to class, which fails to account for vertical relationships, and primordialism, which fails to account for networks between ethnic groups, clientelism provides an effective way to gauge power relations in developing countries. It avoids pejorative terms such as corruption which suggest unorganized or intentionally damaging behavior. ${ }^{7}$

Clientelism differs from neopatrimonialism, which advantages the top of a steeper pyramid. The difference between clientelism and neopatrimonialism has important implications for decentralization. Decentralization eliminates the top of the pyramid; in a clientelist system, this leaves a number of mid-level actors in positions of power, allowing elements of previous systems to survive. For neopatrimonial systems, eliminating the patron will either change the system or result in another patron taking top spot. For Indonesia, "a neopatrimonial framework has difficulty explaining the resilience of pervasive patronage after the fall of a superpatron." 8 Clientelism offers a superior lens for this case due to the strength of mid-level actors.

How do democratization and decentralization alter clientelist systems? Democracy alters patron-client relationships by improving the bargaining power of clients. It may strengthen clientelism by defining the currency of support; leaders can "deliver favours to their supporters in return for votes." In the case of Thailand, voting has reinforced clientelism in rural areas, as local strongmen (Chao Pho, godfathers) have mobilized clients to deliver them into office. ${ }^{10}$ Democracy defined as voting is clearly insufficient. It should empower social actors to resist vertical networks and challenge one-party rule, which is frequently a vehicle for patronage; democracy "empowers the powerless... and severs the psychological and structural bonds of clientelism." "11 The impact of democracy on clientelism largely depends on the depth of democratization: public participation; interest groups, political parties, and civil society. Like state incapacity, clientelism may be entrenched by decentralization if democratization has not first taken root. If a state is democratic and strong, decentralization may provide local accountability, responsibility, and sustainability. Without democracy, decentralization can simply remove the top layers of clientelism and entrench mid-level corruption, creating authoritarian enclaves and further undermining state capacity.

Clientelism is both a cause and an effect of weak states and strong societies. Personalist networks compete with state power, drain resources, and capture state offices. The relationship 
between a weak state, clientelism, and illegal logging is complex. The three are mutually reinforcing, while clientelism and illegal logging are also indicators of state capacity. To combat illegal logging, a strong participatory state must come first. These are the goals of democratization and decentralization, but are not always the result. To enhance state power and mitigate clientelism, democracy must first be relatively entrenched, including a turnover of leaders, free media, active NGOs and a public which holds its leaders accountable. Decentralization is only effective if democratization is successful; otherwise, it will weaken state capacity and entrench clientelist networks, leading to an increase in illegal logging.

\section{II: Centralized Power \& Illegal Logging in Indonesia}

Having detailed the theories which drive this study, I discuss them in terms of an increasingly decentralized Indonesia. After describing the weak, clientelist, centralized state that was the New Order, I look at the environmental consequences. In the next section, I will detail Indonesia's radical decentralization and assess what this means for illegal logging.

For three centuries, the Dutch ruled the East Indies through local chiefs, but exercised direct control of rubber, tea, coffee, and sugar plantations. Dutch rule became increasingly centralized in the nineteenth century as high colonialism took hold in response to a series of conflicts. When Indonesia proclaimed its independence, the Dutch now demanded a federal system that could protect Christian enclaves, but Sukarno believed this would produce too much instability given ethnic and religious conflicts throughout thousands of islands. Sukarno "established continuity with the Dutch colonial administration, in which a central government presided over the regions." ${ }^{2}$ The President faced strong opposition on this from Vice President Hatta, Muslim leaders, and regional military commanders. Sukarno began as a democrat, but as religious, ideological, and military rebellions grew, he shifted to 'Guided Democracy', a semiauthoritarian system in which Sukarno balanced the military and communist forces through strong executive rule. General Suharto took power through a 'creeping coup' after a muddled strike by communist leaders against the military, proclaiming a 'New Order' for Indonesia. ${ }^{13}$

The New Order was not a dictatorship in the strictest sense, but rather an oligarchy. Suharto did not rule directly. The "father of development" (Bapak Pembangunan) ensured that his extended family as well as friends from the business community and military were granted monopolies, state corporations, and government agencies. Suharto and his circle controlled 
access to every level of power, leashing political parties, NGOs, and religious organizations. Any hopes of local autonomy that survived Sukarno were eliminated by Suharto in the name of security and development. The New Order was "modernization theory made flesh." 14 Technocratic Five Year Plans focused on resource extraction, energy megaprojects, and transmigration. Contracts were denied to regional elites in favour Suharto's allies, organized through the Golkar Party. Pertamina, the state oil company, personified the effects of Bapakism (fatherly rule). Ruled by Suharto's friend General Ibnu Sutowo, Pertamina was given hefty portions of state revenue, foreign investment, and control of oil reserves. The company went bankrupt in the 1970s, with the state inheriting billions in debt; "long chains of clients extending downward from the directors' closest confidents prospered while the organizational objectives failed." 15 Clientelism drained state revenue and marginalized traditional elites, meanwhile enriching those with connections.

Nowhere was this as evident as the forestry sector. Indonesia is home to vast rainforests, which under Indonesian law, belong to the state. Suharto granted access to nearly half of Indonesia's forests to his friends Bob Hasan ("the Plywood King") and Prajogo Pangestu. Local officials either rented access from these officials or turned to illegal logging. Yields were not sustainable, reforestation was rare, rainforests were clearcut, rivers became silted, and landslides killed hundreds. Corruption was rampant at all levels; in 1993, Tommy Suharto and Bob Hasan embezzled \$87 million from Greenpeace’s Forest Renewal Programme, but were never convicted. ${ }^{16}$ The state saw only 8 to $30 \%$ of forestry revenue, losing rents, legitimacy, control, and the ability to reharvest. ${ }^{17}$ By the 1980 s, powerful military and corporate actors had evolved their own networks beyond the Suharto family.

Throughout the 1990s, illegal logging and draught led "the Haze" that choked out much of Southeast Asia. In 1997, forest fires blanketed Singapore, Brunei, and Malaysia in smoke, costing the region billions of dollars and threatening the health of millions. Satellites found the cloud reached three million square kilometers. This led to an Association of Southeast Asia (ASEAN) resolution to tackle illegal logging, but once again in 2006, the intersection of clearcuts and late monsoon rains created a regional cloud.

The forestry sector shows how a centralized, clientelist regime can weaken state capacity and lead to economic, human, and environmental disasters. Clientelism was entrenched by the New Order; even state loans were "underpinned by personal connections, not by collateral or 
persuasive investment proposals." ${ }^{\prime 18}$ This is a prototypical weak state, where the state and its laws are secondary to personal profits and social networks. In 1998, this contributed to the collapse of Indonesia's economy and the fall of Suharto, bringing five years of chaos and threatening the country with disintegration.

\section{III: Reformasi's Radical Decentralization}

In recent years, Indonesia has undertaken radical experiments in political institutions. Decentralization was sought as a means to appease regional sentiments, make the government more responsive to local needs, and decrease the burden on Jakarta. Indonesian reforms are part of a global trend in which "local officials are thought to be more aware of local needs, better situated to respond to these needs, and more accountable to local constituents for the results."19 Decentralization is also a means to improve participatory democracy; because states are not likely to shrink, "other ways must be found to reduce the scale of democracy...this means federalism and regional autonomy." 20 But this is no golden key to progress. Although decentralization promotes participation and reduces the likelihood of dictatorship, it may also lead to "authoritarian enclaves" in peripheral regions if the central government and society are too weak. ${ }^{21}$ We must not forget that Indonesia and several other countries became centralized regimes in partial response to overcome regional military units and avoid ethnic conflict. The stakes of decentralization are high, however the potential benefit to a large country riddled with separatism and incapacity appealed to reformers.

The task of drafting Indonesian decentralization laws fell to political scientist Ryaas Rasjid and seven of his colleagues. The results were Law 22/1999, the political aspects of decentralization, and Law 25/1999, which focused on fiscal matters. The laws devolve power to the district (Kabupaten), as opposed to the provincial government, which became an extension of the central government. Article Seven of Law 22/1999 reads that district governments are responsible for everything "except in the fields of international policies, defence and security, judiciary, monetary and fiscal policy, religion, and authorities in other fields." ${ }^{22}$ District governments inherit whatever is left, such as taxation, health, education, and resource management. In Article Ten, district governments are given the responsibility for natural resources and the environment. Districts retain $64 \%$ of resource revenue, with $16 \%$ going to the province and $20 \%$ to Jakarta. Implementation has been occurred at breakneck speeds, completed 
nineteen months after the laws were passed. In 2000, thousands of bureaucrats were transferred to the districts. Indonesian authorities have created five new provinces, over one hundred new districts, and countless new sub-district and village units. House speaker Amien Rais even championed a federal model. It is important to note that districts have gained responsibility, not authority, and that Indonesia remains a de facto unitary state.

Democratization may undermine or entrench clientelist systems. Free and fair elections have returned new governments, including a directly elected President and, by the end of 2006, 90\% of provincial and district heads were directly elected as well. Civil society, an independent media, new parties, and an increasingly capable anti-corruption movement have played important roles in mitigating clientelism. But democratization has proceeded unevenly, creating a "Java-Outer Islands" dichotomy in which isolated governments retain characteristics and leaders from the New Order. ${ }^{23}$ Rural areas lack political opposition, an effective civil society, or an independent media. As a result, "Suharto has gone, but those he favoured continue to flourish." 24 Due to a lack of pro-democracy forces, democratization has not changed clientelism a great deal in Outer Indonesia.

The ambiguity and pace of Indonesian decentralization has resulted in criticism. The World Bank alleges that "two years in, it is unclear what has been decentralized." 25 First, district power is a residual of federal responsibilities, resulting in confusion. Second, state agencies and old laws have not been updated to reflect these changes. For instance, the Forestry Act still refers to provincial responsibilities which no longer exist. ${ }^{26}$ Clashes between federal, provincial, and district authorities have become more common. Third, no minimum standards have been adopted for policies such as education, health, or resource extraction. Fourth, there is a lack of human and technical resources in district governments, creating low quality, weak governments, especially in rural areas. According to the World Bank, district governments are "very much a product of the New Order Regime... and without an authority figure, are free to pursue rent unchecked." 27 They add that "big ticket corruption may have fallen in absolute terms, while petty corruption under weaker political management may have increased."28

Despite these important criticisms, in some respects the 'Big Bang' has gone surprisingly well, with stability, economic growth, civil society, and democracy taking root across the country. In parts of Indonesia, reforms have weakened the political power of the military and business, reduced corruption, and strengthened the rule of law. New societal actors, such as the 
media and NGOs, are critical of the government but mostly supportive of the state and its rules. Elections have produced a turnover in government officials, new political parties, and a more legitimate state. But again, democratization has proceeded slowly in Indonesia's periphery, where Suharto-era local leaders remain in control of corrupt, weak local states.

Figure One illustrates clientelism under Suharto. The line on the right is an example of a patron-client network. Figure Two illustrates changes since 2001. In effect, the top layers have been peeled back, leaving the numerous district leaders at the top of a modified pyramid.

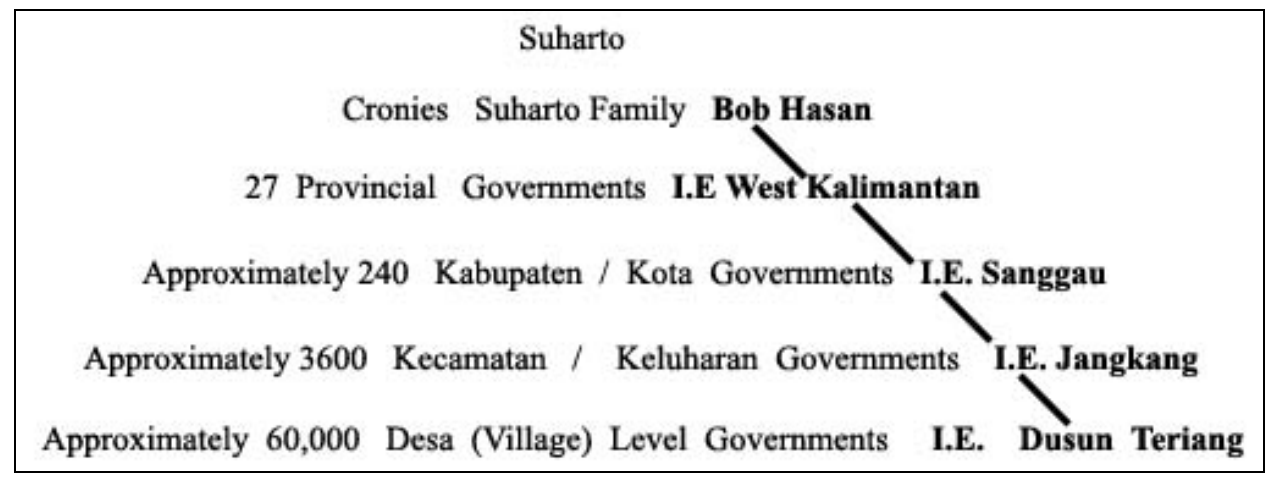

Figure 1: Clientelism during the New Order

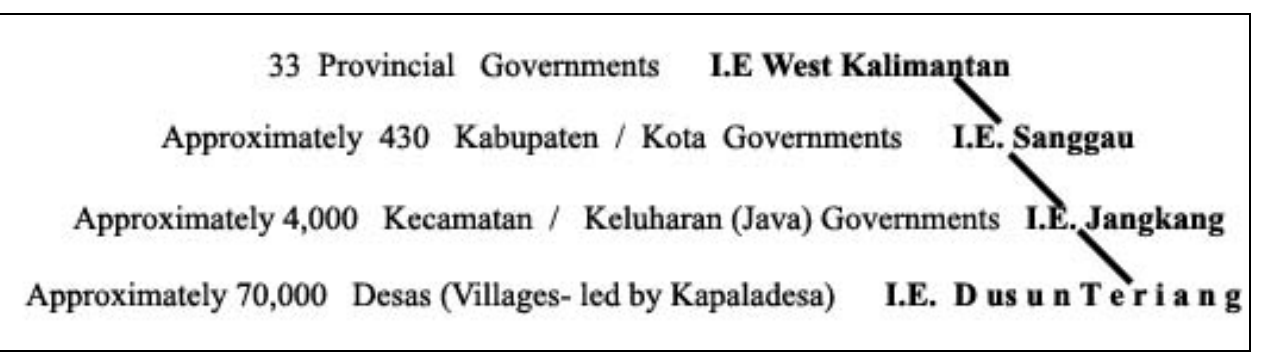

Figure 2: Clientelism after the New Order

How should we react to disparate reports on institutional change in Indonesia? To assess the effects of decentralization on state capacity, the state must be disaggregated by administrative level. The central government is strongest due to its expertise, skilled leadership, and economy of scale. With each step towards local government, society's power grows in relation to the state. Especially in a country which has so quickly devolved responsibility to an increasing number of district governments, governments lack the ability to compete with strong societal actors such as corporations, and may even be captured by them. Remote district-level governments lack expertise, stable sources of revenue, and strong societal actors such as civil society or the media, 
but have nonetheless gained substantial powers. Local strongmen and logging companies dominate a number of particularly weak states at the district level. This presents a serious challenge to reformers, and has serious implications in many policy sectors.

Forestry provides an excellent avenue to assess Indonesian reforms. The industry dominates the most remote, least democratic regions, and involves strong stakeholders who resist change. Although difficult to measure, illegal forestry leaves a deeper footprint than do other sectors. Since the fall of Suharto, forestry is "undergoing a transformation to become more fragmented and disorderly...Forestry corruption is being reshaped by the democratic transition and 'messy' decentralization." 29 Meanwhile, district governments have become "more dependent on resource-based revenues [creating] incentives to accelerate land conversion and natural resource exploitation." ${ }^{30}$ Reforms have made forestry revenue especially crucial to the most under-funded Kabupaten, which lack the will or the capacity to enforce environmental standards. As a result, illegal logging continues in specific regions throughout the country.

As noted in Figure Three, official logging has declined since the fall of Suharto. But Indonesia's Department of Forestry's annual report demonstrates that official statistics vary wildly. ${ }^{31}$ According to environmental NGO WALHI, illegal logging now varies considerably by district. $^{32}$ It seems that logging has increased, but official logging has decreased, suggesting that the state remains incapable of asserting control in this policy area. Although it is too early to tell if five years of reform have made significant changes in forest management, there are a few indicators available. ${ }^{33}$

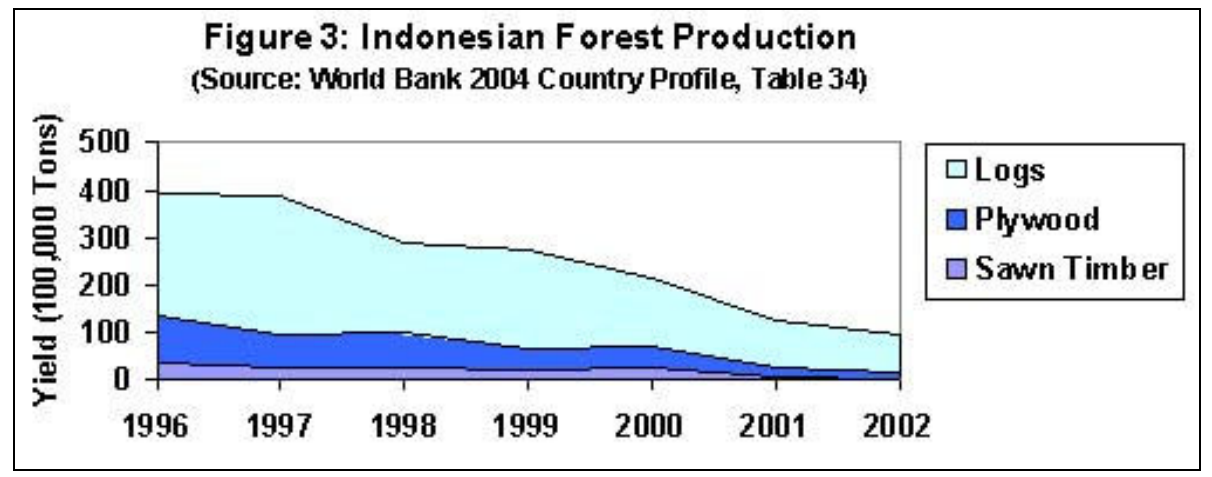

An important indicator is the shift from the HPH (Hak Pengusahaan Hutan, Natural Forest Concession) to the HPHH (Hak Pemungutan Hasil Hutan, Forest Product Harvest License) 
system. The number of HPH have fallen from a dozen to zero in North Sumatra since 1998, whereas HPHH, smaller concessions granted by district governments, increased a thousand fold. In 2000, the Ministry of Forests realized that HPHH grants were out of control and rescinded the law, but many district heads (Bupati) ignored the ruling, claiming their right to local revenues. ${ }^{34}$ The HPHH windfall and subsequent spike in logging was heaviest in Kalimantan and Papua, the most remote and logging-dependent regions in the country.

Early evidence points towards tremendous fluctuation in permit grants according to direct elections for Bupati. In Tapanuli Selatan (TAPSEL) district in North Sumatra, the changeover of Bupati from Saleh Harahap to Ongku Hasibuan has brought tremendous changes in forestry management. ${ }^{35}$ In Langkat district in the same province, local elections have not been held yet because the Bupati was appointed just before the new laws took effect, and accordingly, has some of the worst levels of illegal logging in the country. ${ }^{36}$ The same pattern is evident in Aceh, where because of the conflict, Bupati elections only took place in December 2006, and in a handful of districts not until 2008. Post-tsunami reconstruction has been partially undermined by illegal logging controlled by district heads. ${ }^{37}$

The longer the duration between decentralization and elections, the more difficult it may be to curb illegal logging, as districts without changes in governments have had longer to appoint forestry officers and distribute multi-year forestry concessions. Decentralization seems to be paying dividends in regions that had early Bupati elections. These regions have seen more arrests, active forestry police, fewer concessions, and stricter monitoring. In areas with later elections, illegal logging has continued. This suggests that local elections have brought improvements. But in many remote districts, local elections were held early but have not made much progress. According to John McCarthy, "decentralization "has worked to the advantage of entrenched regional elites" because elections have empowered "leaders rather than rural constituencies." 38 Many NGOs in South Kalimantan believe their province is not ready for decentralization, as Bupati have been turned into Raja-Raja Kecil (Small Kings) by the new laws. WALHI and Transparency International allege that where Bupati elections have been held, campaigns have been financed by logging corporations, resulting in heavy vote-buying and few turnovers. ${ }^{39}$ South Kalimantan has among the weakest political parties; candidates here are backed by a number of parties, whereas elsewhere, they are more likely to be members. The exception in South Kalimantan is in the capital, Banjarmarsin, where the new Bupati Yudhi 
Wahyuni, a member of Amien Rais' PAN, has clashed with district leaders by leading local NGOs in an anti-corruption pilot project.

Three types of districts emerge from this initial fieldwork. First are districts with active civil societies, strong political parties, greater economic development, less dependency on single industries, and greater cooperation with provincial forestry bodies. TAPSEL and Banjarmarsin have each benefited a great deal by direct local elections and decentralization. Second are districts with steeper clientelist pyramids, more money politics, and vested interests in the status quo. Districts in Kalimantan show that direct elections are not always effective, and where they are not, decentralization can entrench illegal logging. ${ }^{40}$ Finally, many regions have yet to hold direct elections, and show trends towards more illegal logging. In Aceh and Langkat, it is unclear if recent or upcoming elections will arrest such trends, or if the longer duration of newly powerful, non-elected Bupatis will make change more difficult.

\section{IV: Looking Forward: Possible Solutions \& Tentative Conclusions}

Without a change in local politics, decentralization can allow the inmates to run the asylum. According to Larry Diamond:

Where hierarchical chains of particularistic, patron-client relationships are already the dominant mode of politics, shifting discretionary financial authority from the central to the local level may simply shift the locus of clientelism and corruption from the central to the local arena, making these problems even tougher to control because of the absence of the strong parties and countervailing interests that are found at the national level. ${ }^{41}$

Kang makes similar observations in South Korea; authoritarian governments "eliminated the middleman, and while you had to pay for access, you could do it at the top levels, and not worry so much about the bureaucracy." 42 This phenomenon has also been documented in Eastern Russia. $^{43}$ Where democratization is ineffective, decentralization entrenches clientelism. Where democracy works, decentralization does as well. In large developing countries, each outcome will likely be found due to inequalities between districts.

For decades, Indonesia has been a weak, clientelist state. Democratization has brought many reforms, removed corrupt leaders, and entrenched the rule of law. Decentralization has enhanced democracy through greater participation and local leadership. Indonesian reforms are largely premised on the ability of "civil society organizations and the media [to] monitor and

criticize government performance." ${ }^{44}$ The World Bank notes that while government monitoring 
of illegal logging has decreased, civil society control has become a valid contributor in its place. $^{45}$ But where democracy and civil society are weak, the ghosts of the New Order remain. Clientelism and state incapacity are still prominent, made worse by decentralization, which has granted substantial power to local strongmen. Illegal logging provides an avenue to gauge the effects of decentralization on state capacity and clientelism, as well as discuss important ecological issues.

Thus far, evidence of the effects of decentralization is anecdotal and mixed. It is too early to be sure what the effects of district political power will be on the environment or state capacity. It seems clear that some districts have benefited from local elections, improving forestry management even in the eyes of critical local NGOs. It is also safe to say that decentralization has entrenched clientelism in remote regions. More research is necessary as decentralization progresses to clarify the direction of democratization in remote districts.

Possible solutions may include greater federal oversight, clearer environmental laws, rotating bureaucrats from more prosperous regions, provincial policing, empowering civil society, rural education, or greater foreign pressure on corporations. While much remains to be done, the importance of the study is clear. The intersection of democratization and decentralization has concrete policy implications for environmental sustainability, local government accountability, and academic importance for several bodies of theory.

\footnotetext{
${ }^{1}$ The project will explore variation among sub-national government capacity to curb illegal logging in Indonesia. It focuses on subnational units at various levels of government and in a range of provinces. Tentative cases include the province of North Sumatra, a district in Aceh, two districts and one sub-district in East Kalimantan, and one district and two sub-districts in South Kalimantan. I expect the greatest variation to be at the district level, however I also disaggregate districts into sub-districts to gauge variation among specific villages. My approach is influenced by Atul Kohli's study of political disorder in India. Kohli believes that "any satisfactory account of India's changing authority patterns must focus simultaneously on the center, the states, and local politics." Not only does Kohli study various levels of government, he ensures variation among them according to level of development and form of instability. For Indonesia, Aceh represents a resource-rich region impoverished by military rule. North Sumatra represents a stable, relatively prosperous case with an active civil society. East Kalimantan has a diversified economy which includes oil deposits, as well as overland routes to Malaysia which facilitate illegal logging. South Kalimantan's economy is more dependent on forestry, isolated, and home to a greater degree of traditional rule. For each, forestry is central to the economy. Atul Kohli, Democracy and Discontent: India's Growing Crisis of Governability (Cambridge: Cambridge University Press, 1990), 11.

${ }^{2}$ Theda Skocpol, "Bringing the State Back In: Strategies for Analysis in Current Research," in Bringing the State Back In, edited by Peter Evans et al (New York: Cambridge University Press, 1985), 20.

${ }_{3}^{3}$ Joel Migdal, Strong Societies and Weak States (Princeton: Princeton University Press, 1988), 4.

${ }^{4}$ Joel Migdal, "The State in Society: An Approach to Struggles for Domination," in State Power and Social Forces, edited by Joel Migdal et al (Cambridge: Cambridge University Press, 1994), 33.
} 
${ }^{5}$ Peter Dauvergne, Shadows in the Forest: Japan and the Politics of Timber in Southeast Asia (Cambridge: MIT Press, 1997), 51.

${ }^{6}$ Migdal, Strong Societies and Weak States, 32.

${ }^{7}$ James C. Scott, "Patron-Client Politics and Political Change in Southeast Asia," The American Political Science Review, Volume 66, Issue 1 (March 1972), 91.

${ }^{8}$ Dauvergne, Shadows in the Forest, 48. In 1994, Dauvergne argued that Indonesia was a clientelist state because networks were not dependent upon Suharto. Years of attempted reforms have proven this assessment correct.

${ }^{9}$ Michael Goldsmith, "Local Autonomy: Theory and Practices," in Challenges to Local Government, edited by Desmond S. King and Jon Pierre (London: Sage Publications, 1990), 21.

${ }^{10}$ Ruth McVey, Money and Politics in Provincial Thailand (Honolulu: University of Hawaii Press, 2000).

${ }^{11}$ Larry Diamond, Developing Democracy: Towards Consolidation (Baltimore: Johns Hopkins University Press, 1999), 244.

${ }^{12}$ Mark Turner and Owen Podger, Decentralization in Indonesia: Redesigning the State (Canberra: Asian Development Bank, 2003), 9.

${ }^{13}$ John Roosa, Pretext for Mass Murder: The September $30^{\text {th }}$ Movement and Suharto's Coup D'Etat in Indonesia (Madison: University of Wisconsin Press, 2006).

${ }^{14}$ Patrick Smith, "What Does is Mean to be Modern? Indonesia's Reformasi," Washington Quarterly, Volume 22, Issue 4 (Autumn 1999).

${ }^{15}$ Karl D. Jackson, "Bureaucratic Polity: A Theoretical Framework for the Analysis of Power and Communications in Indonesia," in Political Power and Communications in Indonesia, edited by Karl D. Jackson and Lucian Pye (Berkeley: University of Berkeley Press, 1978), 15.

${ }^{16}$ Richard Robson, "Politics \& Markets in Indonesia's Post-Oil Era," in The Political Economy of Southeast Asia, edited by Garry Rodan et al (Oxford: Oxford University Press, 1999), 34.

${ }^{17}$ Dauvergne, Shadows in the Forest, 77.

${ }^{18}$ Dauvergne, Shadows in the Forest, 64 ,

${ }^{19}$ Eric Thun, "Keeping up with the Jones': Decentralization, Policy Imitation, and Industrial Development in China," World Development, Volume 32, Issue 8 (2004), 1290.

${ }^{20}$ Diamond, Developing Democracy, 119.

${ }^{21}$ Diamond, Developing Democracy, 133.

${ }^{22}$ The Republic of Indonesia, "Law 22 / 1999: Regarding Regional Governance, Chapter IV: Regional Authorities, Article 7."

${ }^{23}$ David Ray and Gary Goodpaster, "Indonesian Decentralization," in Autonomy and Disintegration in Indonesia (London: Routledge Curzon, 2003), 83.

${ }^{24}$ World Bank, "Combating Corruption in Indonesia: Enhancing Accountability for Development," (Oct. 2003), 1.

${ }^{25}$ World Bank, "Centralizing Indonesia: Regional Public Expenditure Review," Report 26191-IND (June 2003), 10.

${ }^{26}$ World Bank, "Decentralization of Natural Resource Sectors in Indonesia: Opportunities and Risks," Report 23148 (September 2001), 9.

${ }^{27}$ World Bank, "Combating Corruption in Indonesia," vi.

${ }^{28}$ World Bank, "Combating Corruption in Indonesia," ii.

${ }^{29}$ World Bank, "Combating Corruption in Indonesia," 74.

${ }^{30}$ World Bank, "Decentralization of Natural Resource Sectors in Indonesia," ii.

${ }^{31}$ For instance, official numbers place sawn timber exports at 2,37,000 $\mathrm{m}^{3}$ ( $\$ 2.04$ billion) in $1995,800,00 \mathrm{~m}^{3}(\$ 850$ million) for $1996,60,000 \mathrm{~m}^{3}$ ( $\$ 50$ million) in $1997,20,500,000 \mathrm{~m}^{3}$ ( $\$ 68.76$ billion) in $2000,12,310,000 \mathrm{~m}^{3}$ ( $\$ 5.19$ billion) in 2001, and $392,590,000 \mathrm{~m}^{3}$ ( $\$ 1.91$ billion) in 2002. It is unclear how production increased thirty fold from 2002 to 2003, while profits fell by one third. Departemen Kehutanan, Statistik Kehutanan Indonesia 2003, "Perkembangan Ekspor Kayu Olahan Sepuluh Tahun Terakhir" (Jakarta: Departmen Kehutanan, 2005), 175.

${ }^{32}$ WALHI, "Laporan Investigasi Hutan Sumatera Utara di 11 Kabupaten" ("An Investigation into the Forests of Eleven Districts in North Sumatra"), private report given to author (August 2005). In Pasar Rawa Village, semiintensive forestry has stopped almost entirely according to both NGO and Government Reports, whereas in neighbouring Pelan Gebang, it has increased from 500 to 600 hectares in four years.

${ }^{33}$ One possible solution to this research problem was found by researchers at CIFOR, who focused on the 26 pilot districts which began the decentralization process in 1995. Their indicators show a significant increase in illegal logging in these regions compared to recently decentralized regions, lending support to the argument that decentralization requires democratization. This said, it is reasonable to expert these pilot districts to have 
exaggerated results, as they were chosen because they were led by loyal Golkar leaders, and the chaos of 1997-2001 allowed these districts to expand logging faster than typical districts.

${ }^{34}$ Series of interviews in South Kalimantan and North Sumatra, Summer 2006. See also Center for International Forestry Research (CIFOR) decentralization briefings, www.cifor.cgiar.org/publications.

${ }^{35}$ Saleh Harahap was a longtime GOLKAR leader for North Sumatra, and was investigated for several counts of election fraud in 1999 by the electoral commission. Pak Ongku, http://ongku.hasibuan.tripod.com, is supported by the Prosperous Justice Party (PKS), which joined a Green alliance-Islam and environment- in July 2006 with WALHI. According to the North Sumatra Forestry Department, TAPSEL has seen a quick turnaround, with a new sense of cooperation between the district and forestry police, leading to a swath of arrests in early 2006. Interview with Rura Ginting, Department of Forestry in North Sumatra, Summer 2006.

${ }^{36}$ Langkat also has high levels of illegal logging because it borders Leuser National Park on the Aceh border, making it a clearing house for illegal logs. Langkat has seen dozens of floods which have claimed hundreds of lives in the past decade, which foreign and local NGOs, as well as Bupati Syamsul Arifi,n attribute to illegal logging. Aid money to victims of landslides such as in Bohorok in 2003 has not made it to the villagers. CBC News, "Flood Kills 66 on Indonesian Island" (4 November 2003). Interviews with Hardi Moenthe, OPPUK, and Ken Norton, Media Indonesia, June 2006.

${ }^{37}$ In West Aceh, highway reconstruction paid for by the Japanese Government was diverted inland and land cleared for German Red Cross housing sites. But the route and land picked by district authorities was swamp, and a new site had to be found. The logs from the old and new sites were shipped to North Sumatra for certification so they could be resold to reconstruction projects, where several trucks were intercepted by North Sumatra's forestry police. In June 2006, I visited the site, finding approximately 50 persons operating chainsaws in broad daylight, who admitted the wood was bought by the district government for reconstruction. Series of interviews, West Aceh, 2006.

${ }^{38}$ John F. McCarthy, "Changing to Gray: Decentralization and the Emergence of Volatile Socio-Legal Configurations in Central Kalimantan, Indonesia," World Development, Volume 32, Issue 7 (2004), 1200.

${ }^{39}$ Many NGOs believe the new Governor of South Kalimantan, Rudy Arifin, is heavily involved in illegal logging and coal mining. Arifin beat the PKS candidate in the 2005 elections by $1 \%$ of the vote. Similar sentiments can be found for Kota Baru Bupati Sjachrani Mataja, an unaffiliated candidate who won with $32 \%$ of the vote. Interview with Arief, Transparency International Indonesia, July 2006.

${ }^{40}$ Another way of putting the difference between these two types of regions is found in the rational choice literature. De Mesquita et al argue that in areas with smaller selectorates (the number of groups necessary to form a winning coalition), in our terms with steeper clientelist pyramids and weak political actors, fewer interests must be satisfied by winning parties and local power remains concentrated. But in areas with active civil societies, political parties, provincial authorities, and other societal forces, the selectorate is larger, and alternative winning coalitions are possible, with a wider base to ensure decisions conform to the public good. See Bruce Bueno de Mesquita, Alastair Smith, Randolph M. Siverson, and James D. Morrow, The Logic of Political Survival (Cambridge: MIT Press, 2003). Thank you to Nathan Allen for pointing out this connection.

${ }^{41}$ Diamond, Developing Democracy, 133-134.

${ }^{42}$ David C. Kang, "Bad Loans to Good Friends: Money Politics and the Developmental State in South Korea," International Organization, Volume 56, Issue 1 (Winter 2002), 192.

${ }^{43}$ Please see D.J. Peterson, "The Regionalization of Russia's Economy and Its Impact on the Environment and Natural Resources," in Beyond the Monolith: The Emergence of Regionalism in Post-Soviet Russia (Baltimore: Johns Hopkins University Press, 1997), pp. 145-167.

${ }^{44}$ Turner and Podger, Decentralization in Indonesia, xiv.

${ }^{45}$ World Bank, "Combating Corruption in Indonesia," 3. 